\title{
CERAMAH EDUKASI DIGITAL MARKETING PADA GKI TAMAN ARIES DAN GKI KEMANG PRATAMA BEKASI
}

\author{
Selvi Esther Suwu \\ Pendidikan Ekonomi, Universitas Pelita Harapan \\ selvi.suwu@uph.edu
}

\begin{abstract}
Abstrak
Adanya pandemi pada tahun 2020 mengubah kehidupan perilaku pembelian masyarakat yaitu yang biasanya berbelanja di pasar tradisional dan modern karena takut dan himbauan dari pemerintah untuk tetap melakukan segala kegiatan dari rumah, beralih berbelanjapun dari rumah. Dampaknya banyak toko dan pusat perbelanjaan yang tutup dan mengakibatkan banyak orang yang terkena PHK. Covid19 ini tidak dapat diprediksi kapan akan berakhir dan orang tetap harus berjuang untuk hidup, maka dengan latar belakang ini tujuan dari PkM GKI Taman Aries dan GKI Kemang Pratama mengadakan acara untuk memenuhi kebutuhan jemaat dan masyarakat yang memerlukan tambahan pengetahuan mengenai materi pelajaran ekonomi secara umum agar bisa membuat usaha atau mempertahankan usahanya dengan upaya-upaya yang lebih kreatif. Peserta berasal dari berbagai daerah di Indonesia mencapai 448 orang di PkM GKI Taman Aries dan di GKI Kemang Pratama peserta dapat melihat di YouTube karena acara disiarkan secara langsung. Penulis sebagai dosen merespon acara ini dengan menjadi pembicara mengenai digital marketing sebagai bagian dari PkM. Metode pelaksanaan PkM berupa ceramah edukasi dengan menggunakan media internet yaitu Zoom. Hasil yang diperoleh dari kedua kegiatan PkM tersebut adalah peserta berpendapat ceramah edukasi menambah pengetahuan, presentasi yang dilakukan penulis dapat dimengerti dengan jelas, pembahasan secara praktis dan ringkas.
\end{abstract}

Kata Kunci : Digital marketing, online shop, kewirausahaan

\section{PENDAHULUAN}

Semenjak WHO (World Health Organization) menetapkan virus Covid19 sebagai pandemi dunia (Utomo, 2020) dan adanya himbauan kepada masyarakat agar untuk tetap di rumah, mengakibatkan perilaku sebagian besar konsumen di seluruh dunia termasuk Indonesia mendadak berubah. Langkah apapun yang terbaik diambil oleh pemerintah untuk melindungi warganya. Masyarakat menanggapi dengan sikap sangat berhati-hati untuk melakukan konsumsi dan berusaha agar tidak terlalu sering berada diluar rumah. Dampak ini pun dirasakan oleh beberapa pelaku usaha dari berbagai sektor bisnis, seperti perdagangan, akomodasi seperti restoran dan perhotelan, manufaktur, dan lain-lain. Perubahan yang mendadak ini, membuat para pebisnis tersebut merasa kebingungan, bagaimana cara untuk tetap mendapatkan keuntungan ditengah krisis ekonomi seperti sekarang. Tutupnya pusat perbelanjaan, toko, hotel dan sektor pariwisata lainnya berdampak besar bagi perekonomian daerah maupun negara. Indonesia melakukan juga hal tersebut, penutupan pusat berbelanjaan diberlakukan tanpa ada jangka waktu yang dapat dipastikan hal ini diungkapkan Wakil ketua Umum APPBI Alphonzus Widjaja dalam (Santia, 2020).

Mempertimbangkan keamanan kesehatan maka para konsumen lebih memilih untuk melakukan pembelanjaan secara online untuk menjaga diri mereka. Maka dari itu beberapa usaha seperti online shop dengan menggunakan platform

$$
\text { Ekonomi, Sosial, dan Budaya }
$$


media sosial maupun website resmi mendapatkan keuntungan di masa pendemi ini. Menurut (Kotler \& Armstrong, 2008) dalam bukunya penting untuk diketahui oleh pengusaha bahwa pengenalan kebutuhan konsumen menjadi langkah awal untuk melakukan sebuah usaha. Pada saat ini pengusaha harus sadar konsumen tidak bisa bebas pergi keluar rumah dan bahkan mal dan tokopun beberapa tutup, jadi solusi yang terbaik adalah membuka usaha online. Para pengusaha ini memanfaatkan digitalisasi untuk usaha mereka, dan berharap menambah pemasukan lebih besar. Sebagai pengusaha atau calon pengusaha sebaiknya tidak hanya mengerti tentang pemasaran tetapi juga mengenai wirausaha. (Kasmir, 2017) mengatakan, seorang wirausaha harus memiliki banyak ide, ide yang inovatif, yang berbeda dari yang lain. Ide yang berbeda dapat berbentuk suatu kreatifitas, walau tidak mudah seorang calon pengusaha atau pengusaha harus bisa melihat peluang usaha dengan menciptakan produk yang inovatif. Menjadi wirausaha dengan melakukan pemasaran dengan digital marketing tidak mudah, apalagi tanpa pengetahuan dasar mengenainya. Penulis adalah dosen Prodi Pendidikan Ekonomi Universitas Pelita Harapan yang secara umum mengajar mata kuliahmata kuliah ekonomi, salah satunya manajemen pemasaran.

Selain mengajar dan penelitian tugas seorang dosen adalah pengabdian kepada masyarakat, PkM mempunyai beragam bentuk, dosen diharapkan mampu melayani sesuai bidang studi yang diampu. Penulis sebagai dosen tergerak untuk melayani pada bidang manajemen dan bisnis, maka ketika Student Life UPH mengajak bergabung untuk penulis dapat melayani masyarakat berkaitan dengan bidang manajemen pemasaran penulis menyetujuinya. Student Life UPH adalah sebuah wadah bagi seluruh mahasiswa UPH yang memberikan kesempatan kepada mahasiswa untuk menerapkan materi pelajaran yang diterima dalam kelas untuk dipraktekkan ditengah masyarakat yang membutuhkan. Kali ini Student Life bekerja sama dengan Gereja Kristen Indonesia jemaat Taman Aries yang akan mengadakan kegiatan berupa ceramah edukasi dalam bidang ekonomi, hal ini terkait dengan keadaan pembatasan sosial karena Covid19. Kegiatannya diberi nama Community
Entrepreneurship Oinomia (CEO), dalam kegiatan Student Life bersama mahasiswa yang akan mengambil nilai dalam mata kuliah Wawasan Dunia Kristen di Fakultas Liberal Art (FLA Project) bersinergi atau bekerja sama dengan beberapa dosen untuk menjadi pengabdian kepada masyarakat.

Program ini lahir dari kebutuhan GKI Taman Aries untuk membekali jemaat serta masyarakat umum mengenai materi ekonomi secara umum melalui media online agar semakin banyak orang yang mendapatkan pengetahuan dan berharap agar menghasilkan orang-orang yang bisa melihat peluang-peluang usaha kecil menengah di saat masa pandemic Covid19 ini maupun paska setelah pandemik. Kegiatan ini akan dilakukan secara webinar online dengan target peserta yang berasal dari jemaat GKI Taman Aries dan masyarakat yang tertarik untuk belajar untuk membuat usaha baru maupun para pengusaha kecil yang ingin mengembangkan usahanya yang sudah berjalan. Ada 8 narasumber yang akan menyampaikan materi ini yang dibagi dalam 8 sesi dimana pelaksanaannya adalah tgl 23 dan Tgl 24 Mei 2020 serta tanggal 30 Mei dan tgl 31 Mei 2020. Penulis adalah salah satu narasumber yang akan membawakan materi Digital Marketing/Online Shop.

Sesuai paparan di atas maka tujuan dari PkM yang dibawakan penulis adalah untuk melayani jemaat GKI Taman Aries dan masyarakat, dengan memberikan edukasi ekonomi dengan materi Digital Marketing/Online Shop, diharapkan melalui ceramah edukasi ini memberi pembelajaran yang berguna bagi pembekalan untuk melalukan usaha secara online.

Salah satu peserta dalam acara ini adalah majelis dari GKI Kemang Pratama Bekasi, setelah selesai acara beliau menuliskan tertarik untuk mengundang penulis sebagai pembicara mengenai hal yang sama yaitu tentang digital marketing (online shop) di gerejanya pada acara Bincang Jumat Malam di GKI Kemang Pratama Bekasi.

Bincang Jumat Malam (BJM) bertujuan untuk membekali jemaat dengan materi baik yang bersifat pendalaman iman maupun hal-hal praktis sehari-hari untuk meningkatkan kualitas iman jemaat melalui media interaktif/bincang-bincang. Dengan menggundang penulis sebagai pembicara

$$
\text { Ekonomi, Sosial, dan Budaya } \quad 1176
$$


dalam BJM artinya jemaat GKI Kemang Pratama Bekasi diberikan pengetahuan mengenai digital marketing serta bermanfaat untuk membuka wawasan dan membekali jemaat untuk mengembangkan usaha di masa pandemi Covid19 dengan upaya-upaya yang lebih kreatif, karena tidak dapat dipungkiri jemaat GKI Kemang Pratama Bekasi juga terkena dampak dari pandemi Covid19 ini. PKM ini akan membantu jemaat menggunakan peluang berjualan online $\mathrm{di}$ masa pandemi menggunakan digital marketing.

Melihat kebutuhan dari GKI Kemang Pratama Bekasi maka penulis akan memberikan ceramah edukasi pada jemaat/peserta dalam acara BJM dengan materi mengenai kewirausahaan kemudian dilanjutkan ke digital marketing.

Pengetahuan akan kewirausahaan penting karena berkaitan dengan kreatifitas dan inovasi termasuk memberikan motivasi, dalam bukunya (Kasmir, 2017) menulis motivasi untuk maju dan mengembangkan usahanya akan selalu ada dalam diri seorang pengusaha, terutama untuk membuka atau mengembangkan usaha di tengah banyaknya persaingan. Sebagai calon pengusaha atau pengusaha juga tidak akan patah semangat, walau untuk sukses bukan hal yang mudah, perlu kerja keras.

Online Marketing atau Digital Marketing menurut (Kotler et al., 2011), berkembang pesat dan adalah pemasaran langsung yang menggunakan teknologi internet. Lebih jauh lagi penggunaan internet sekarang tidak hanya di komputer tetapi juga di berbagai gadget, sehingga lebih mudah digunakan terutama untuk memasarkan produk.

Manfaat PkM bagi mitra sasaran (GKI Taman Aries dan GKI Kemang Pratama) adalah Peserta BJM bisa terbuka wawasannya sehingga bisa mempertahankan dan bahkan mengembangkan usaha/bisnisnya mengingat banyak Jemaat GKI yang saat ini sangat terdampak usahanya oleh Pandemi Covid19 ini. Manfaat dari kegiatan ceramah digital marketing ini adalah jemaat GKI Kemang pratama mendapatkan pengetahuan baru untuk memulai usaha atau tambahan pengetahuan mengenai digital marketing bagi yang sudah menjalankan usahanya.

\section{METODE}

Bentuk kegiatannya, GKI Taman Aries membuat acara ceramah edukasi kemudian bekerja sama dengan Student Life Universitas Pelita Harapan yang menyediakan beberapa narasumber yang berasal dari dosen yang sesuai dengan bidang studinya) selain itu Student Life juga bersama mahasiswa yang akan mengambil nilai di matakuliah FLA akan membantu pelaksanaan acara ini dengan berkoordinasi langsung dengan dua pihak yaitu GKI Taman Aries. Mahasiswa membantu GKI Taman Aries mempersiapkan acara di pihak lain mahasiswa juga bekerja sama dengan para dosen untuk membantu saat pelaksanaan acara seperti, menayangkan materi di power point, pembagian waktu, dokumentasi dan sebagainya.

Penulis sebagai salah satu pembicara menyiapkan materi berbentuk power point. Kemudian pada tanggal 30 Mei 2020 jam 14.00 menggunakan Zoom akan membawakan ceramah edukasi dengan topik Digital Marketing/Online Shop. Materi akan disampaikan selama 30 menit kemudian setelah itu ada sesi tanya jawab yang akan berlangsung selama 60 menit.

Metode PkM yang dilakukan di GKI Kemang Pratama Bekasi tidak berbeda dengan di GKI Taman Aries. Berbentuk webinar dengan menggunakan media Zoom. Pelaksanaan kegiatan PkM pada:

15-24 Juli $2020=$ Pembuatan materi

27-29 Juli 2020 = Finalisasi materi dan acara

31 Juli $2020=$ Acara $\mathrm{PkM}=$ waktu $=$ 19.00-21.00.

Berikut adalah dua pamflet kegiatan PkM : 


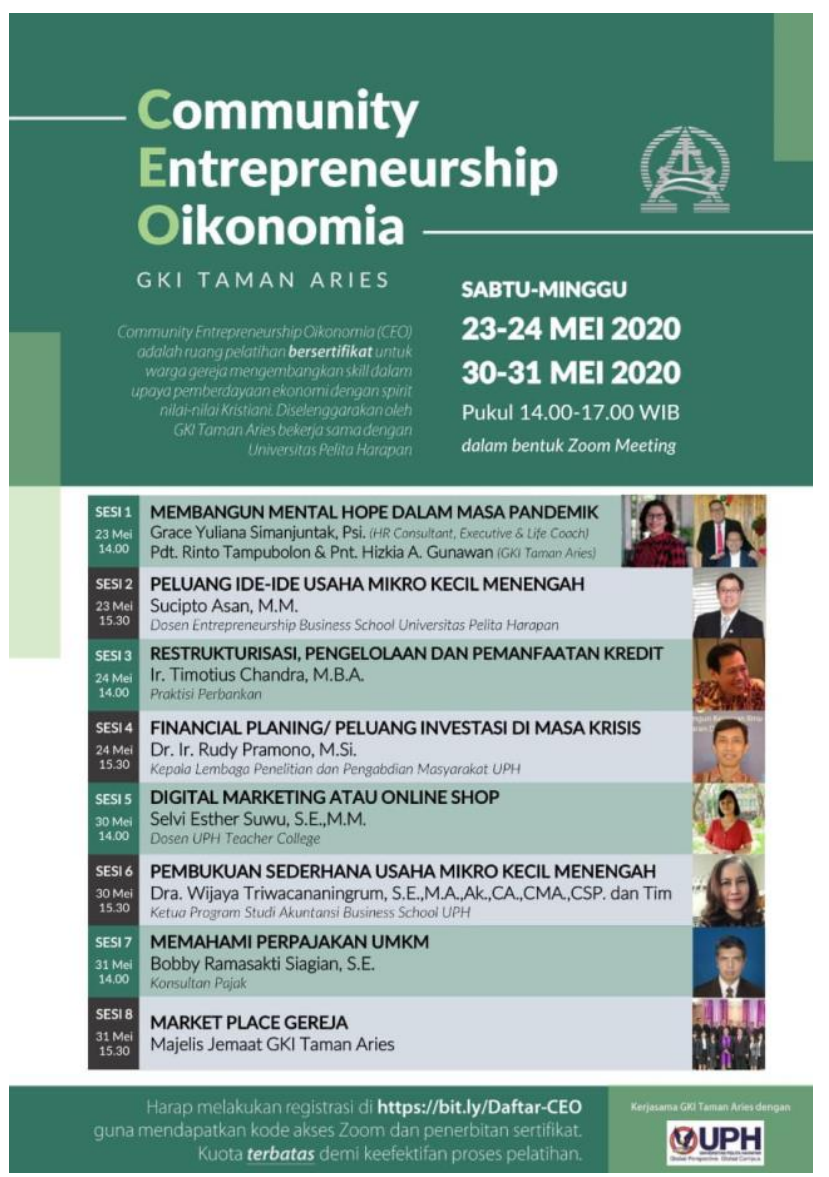

Gambar 1. Pamflet Webinar di GKI Taman Aries

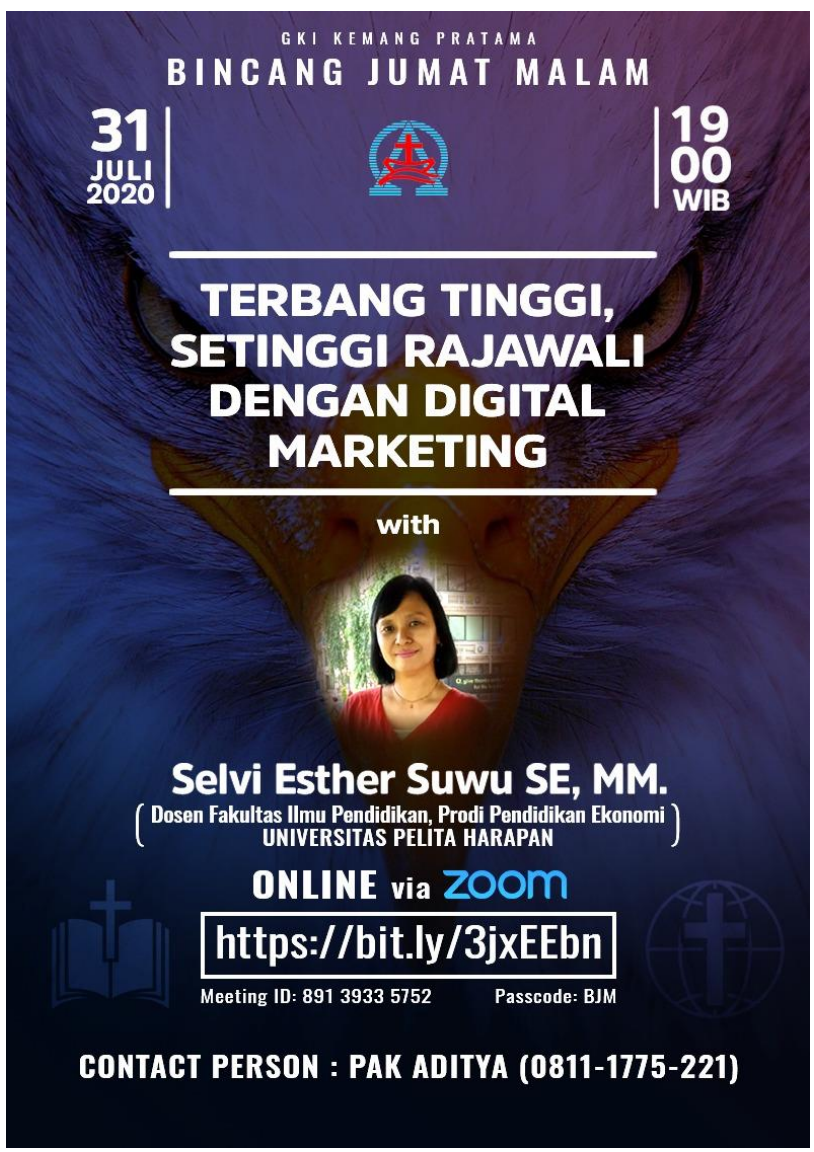

Gambar 2. Pamflet Webinar di GKI Kemang Pratama Bekasi

\section{HASIL DAN PEMBAHASAN}

Kegiatan PkM dilaksanakan dalam webinar dengan power point yang ditayangkan di Zoom. Materi power point untuk PkM di GKI Taman Aries dan GKI Kemang Pratama Bekasi pada dasarnya sama hanya di GKI Kemang Pratama Bekasi, penulis menambahkan materi kewirausahaan.

Menurut (Couter \& Robbins, 2009) kewirausahaan adalah mengejar peluang mengenai perubahan yang orang lain belum tentu tahu. Maka dengan ini penulis merasa harus membagikan materi mengenai kewirausahaan, diharapkan peserta ceramah edukasi dapat melihat peluang-peluang yang ada pada pandemi ini. Berkaitan dengan kewirausahaan seorang wirausaha setidaknya harus mempunyai sikap berani memulai usaha, tidak takut 
rugi, penuh perhitungan, ada rencana yang jelas, percaya diri, bertanggung jawab dan beretika (Kasmir, 2017).

Selanjutnya setelah mengerti tentang kewirausahaan seorang calon pengusaha atau pengusaha harus mengerti konsep pemasaran secara umum, ini seperti yang diungkapkan oleh (Alma, 2009) tujuannya untuk memberikan kepuasan bagi pelanggannya. Ini juga yang dimasukkan penulis dalam materi ceramah edukasi. Selain itu penulis memasukkan unsur promosi dalam bagian pemasaran karena dalam bukunya yang lain (Alma, 2005) mengatakan tujuan promosi untuk meningkatkan penjualan dengan memberikan informasi hingga memberi pengaruh pada pelanggan.

Dalam penelitiannya (Hamdan, 2018) mendapat hasil bahwa adanya revolusi industri 4.0 dengan adanya penggunaan digitalisasi dalam pemasaran berdampak membawa pengaruh pada kewirausahaan yang mandiri. Contoh nyata usaha susu kambing etawa dari penelitian (Fawaid, 2017) memperlihatkan digital marketing system berpengaruh pada penjualan yang meningkat. Bila dilihat dari penelitian-penelitian tersebut memang pada saat ini digital marketing berpengaruh pada kewirausahaan.

Berikut adalah materi secara ringkas saat membawakan PkM di kedua tempat tersebut:

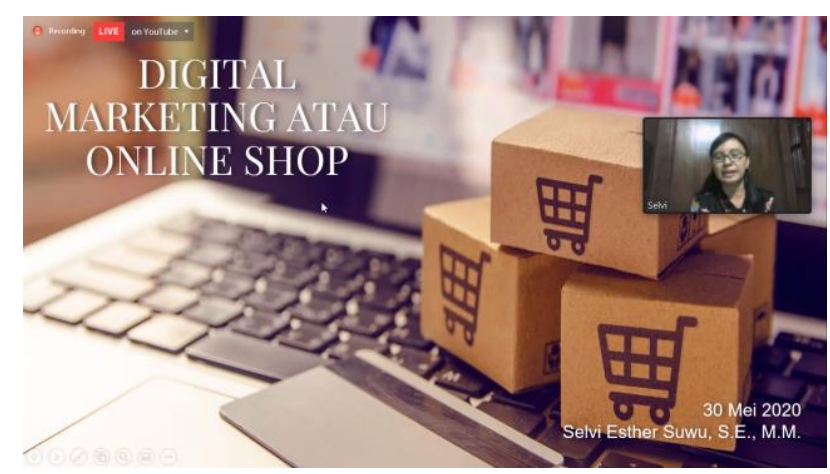

Gambar 3. Penayangan slide pertama ceramah edukasi digital marketing

Penulis membuka ceramah dengan memberi pencerahan akan esensi dari hidup dan bekerja, hal ini dikemukakan agar peserta membuka pikirannya terhadap apa itu bekerja. Mensyukuri kehidupan yang diberikan Tuhan dengan bekerja keras dan memiliki jiwa kewirausahaan, cepat tanggap melihat peluang, jujur dan tidak pantang menyerah. Edukasi mengenai POAC (Planning, Organizing, Actuating dan Controlling) didalam manajemen juga diberikan, bahwa usaha memerlukan pengaturan mulai dari perencanaan, pengorganisasian, implikasi usaha hingga pengendalian. Walaupun usaha tersebut masih baru atau usaha yang kecil tapi $P O A C$ perlu dipelajari agar dari awal usaha dilakukan dengan benar.

Setelah menjelaskan pentingnya pengetahuan $P O A C$, penulis membawakan pengenalan online shop. Dimulai dari definisi online shop kemudian platform yang dapat digunakan sebagai media berjualan online. Pelanggan di Indonesia lebih mengenal platform situs belanja dan media sosial untuk berbelanja online, maka penulis menjabarkan beberapa platform tersebut walaupun tidak detail. Mengetahui beberapa platform belanja/berjualan online harus dibarengi dengan pengetahuan tentang tujuan dan manfaat dari berjualan online, kesadaran akan tujuan dari berjualan online membuat para calon pengusaha atau pengusaha kembali lagi sadar untuk apa mereka membuat usaha secara online. Berbedanya dan persaingan dalam berjualan online dengan berjualan offline mau tidak mau membuat pengusaha berstrategi.

Pembekalan untuk berstrategi dalam berjualan online dibuat penulis dalam bentuk langkah-langkah praktis membuat digital marketing.

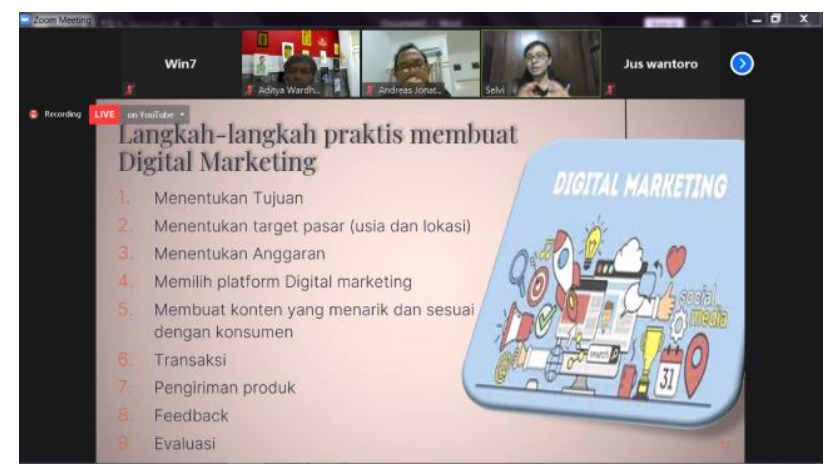

Gambar 4. Penayangan slide langkah-langkah praktis membuat digital marketing 


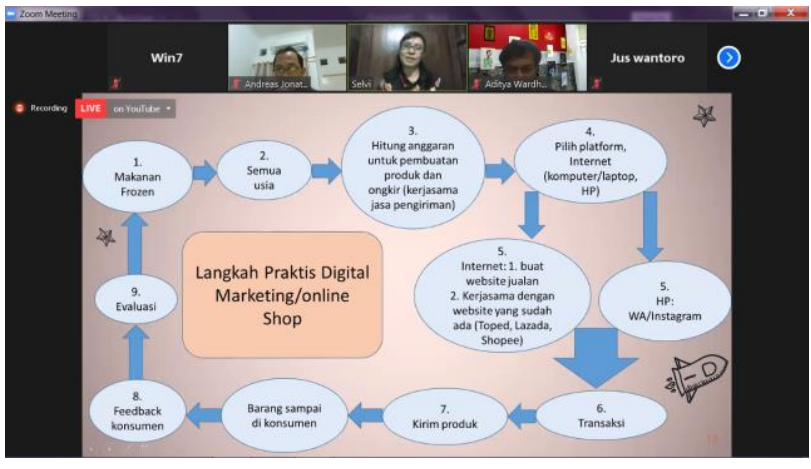

Gambar 5. Penayangan slide bagan langkah-langkah praktis digital marketing

Penentuan tujuan di awal pembentukan digital marketing sangat diperlukan, ini dibuat sebagai langkah awal penentu akan kearah mana usaha berkembannya nanti, di dalam POAC penentuan tujuan bagian dari perencanaan. Selanjutnya adalah penentuan target pasar termasuk usia dan lokasi. Penting untuk diketahui oleh pengusaha siapa target pasar dan di mana akan dipasarkan produk/jasa, walaupun secara online untuk produk makanan yang rentan akan kadaluarsa maka tempat menjadi hal yang perlu diperhatikan, begitu juga jika berjualan produk contohnya berbentuk asesoris untuk wanita dengan harga yang murah, maka ongkos pengiriman barang menjadi perhitungan tersendiri, pelanggan akan memilih membeli di toko online yang jaraknya tidak jauh dari rumah dengan pertimbangan ongkos kirim tersebut. Berikutnya adalah menghitung biaya pembuatan produk bagi yang berjualan online dengan menghasilkan produk sendiri dan biaya pembelian produk bagi yang menjadi reseller. Penghitungan biaya dibutuhkan untuk menentukan harga jual, yang perlu disadari ketika menentukan harga jual produk salah satunya adalah adanya pesaing, bandingkan harga produk yang dibuat dengan harga pesaing, jangan terlalu jauh rentang harganya dengan produk sejenis yang berkualitas sama. Bagian perencanaan masih memikirkan dengan memilih platform berjualan online yang sesuai dengan pengusaha dari aspek modal, pelanggan dan produk tadi.

Setelah menentukan platform yang akan digunakan berjualan online mulai mendesain media yang digunakan misalnya Facebook, Instagram maupun website, sedangkan jika bekerja sama dengan platform website jualan yang sudah ada maka tidak perlu mendesain hanya perlu mendaftarkan usahanya. Tidak lupa juga mempersiapkan pegawai jika memang diperlukan untk produksi atau menyiapkan produk dan sebagainya yang termasuk dalam Organizing di POAC.

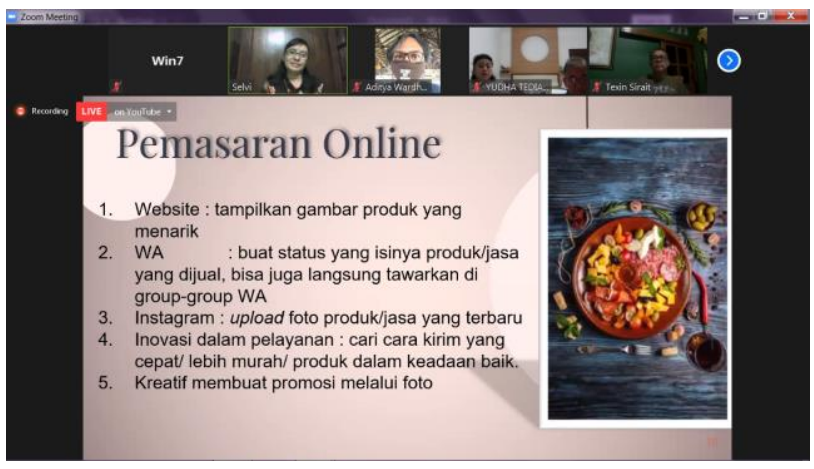

Gambar 6. Penayangan slide pemasaran online

Kegiatan selanjutnya adalah jualan online dengan bertransaksi, dari menawarkan produk yang dipajang di media sosial atau website hingga berinteraksi dengan pelanggan. melakukan jualan online ini masuk di dalam Actuating (POAC). Digital marketing juga memperhatikan reaksi atau respon pelanggan atas produk yang telah dipakai/dikonsumsi, pengetahuan akan respon tersebut berbentuk umpan balik, jika dijualan online adalah berupa testimoni. Testimoni yang baik dari pelanggan akan ditampilkan di platform jualan online dengan harapan dapat menarik pelanggan baru atau pembelian ulang bagi pelanggan lama. Jika yang terjadi sebaliknya maka pengusaha dalam evaluasinya akan mencari kesalahan ada di mana dan akan memperbaikinya. Inilah bagian dari controlling atau pengendalian (POAC). Sampai di sini akan kembali ke penentuan tujuan pada langkah pertama digital marketing juga langkah-langkah selanjutnya seperti tadi.

Pengulangan langkah-langkah dalam digital marketing akan terus terjadi, salah satu yang menjadi pembelajaran bagi pengusaha dalam menjalankan langkah-langkah tersebut adalah interaksi dengan pelanggan. Berinteraksi dengan pelangan memerlukan pengetahuan yang berbeda dari berjualan offline, karena di sinilah terlihat

$$
\text { Ekonomi, Sosial, dan Budaya }
$$


usaha yang berjalan sudah baik atau belum, maksudnya jika di toko offline pengusaha dapat melihat dengan kasat mata perilaku pelanggan terhadap produk atau tokonya tetapi di toko online pengusaha harus jeli melihat perilaku konsumen terhadap produknya. Menghadapi pelanggan online diperlukan teknik agar dapat menarik, maka untuk itu penulis mempersiapkan edukasi tentang pelanggan.

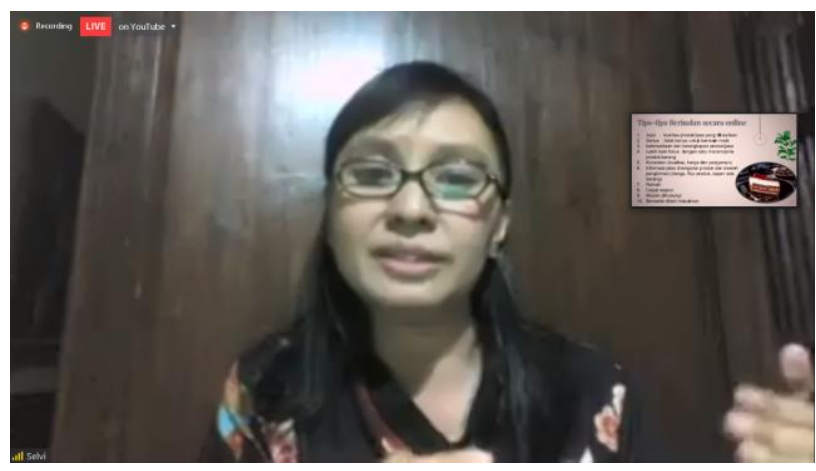

Gambar 7. Foto penulis sedang membahas tips berjualan online

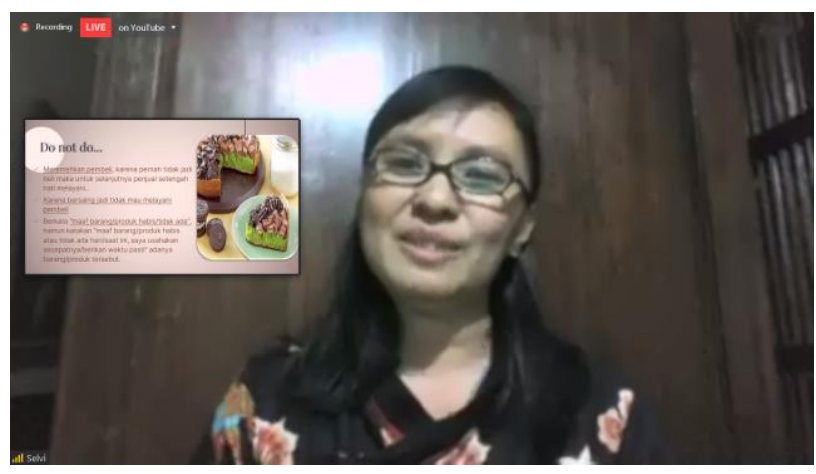

Gambar 8. Foto penulis sedang membahas yang tidak boleh dilakukan dalam berjualan online

Edukasi tentang pelanggan termasuk tips dan apa yang tidak boleh dilakukan pengusaha dalam berjualan online, seperti tips mendesain website hingga tidak membuat status atau memajang foto pribadi yang tak ada sangkut pautnya dengan produk yang dijual di media sosial tempat berjualan, karena ini tidak menarik dan mengganggu pelanggan yang berniat untuk membeli. Tips dan apa yang tidak boleh dilakukan pengusaha adalah akhir dari ceramah edukasi yang dibawakan penulis.
Sebagai penutup dari ceramah edukasi mengenai digital marketing penulis mengingatkan kembali tentang esensi hidup dan berusaha (bekerja), bahwa semua yang dilakukan dan yang didapat dari usaha berjualan online harus disyukuri.

Berikut adalah foto-foto saat acara berlangsung secara online:

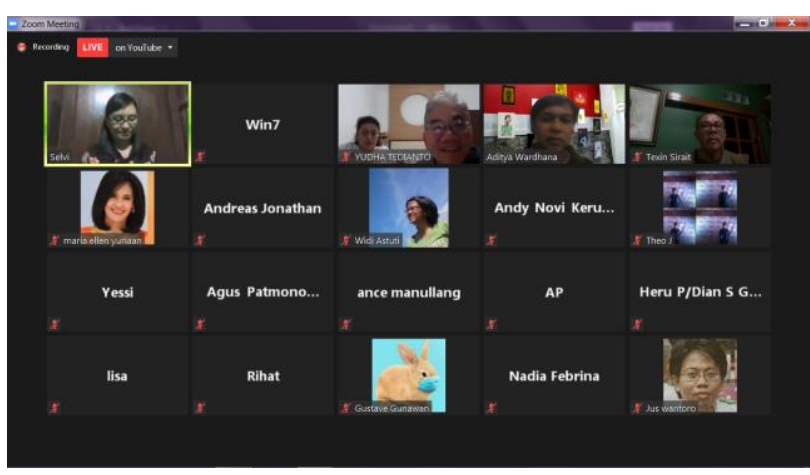

Gambar 9. Foto peserta acara PkM ceramah edukasi digital marketing di GKI Kemang Pratama

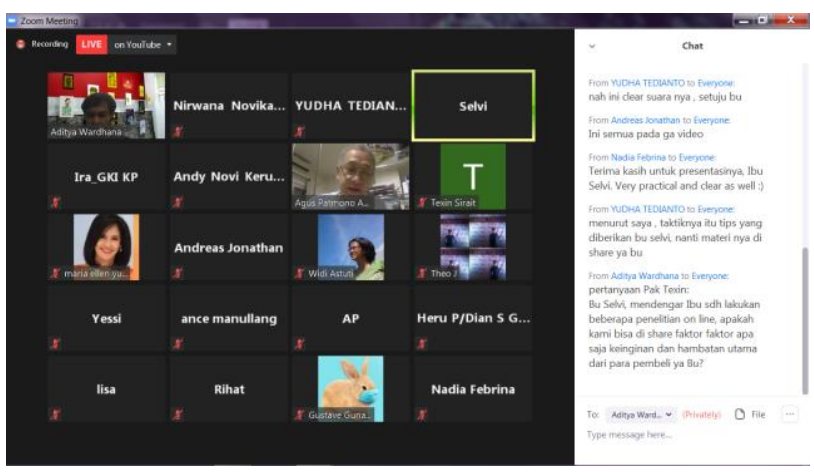

Gambar 10. Foto peserta acara PkM ceramah edukasi digital marketing di GKI Kemang Pratama beserta pertanyaan dari peserta

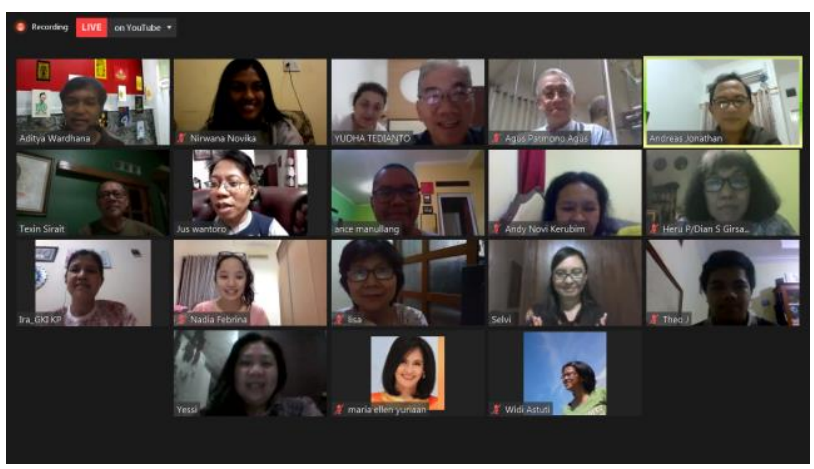

Gambar 11. Foto peserta acara PkM ceramah edukasi digital marketing di GKI Kemang Pratama

Ekonomi, Sosial, dan Budaya 
Hasil PkM di kedua tempat dapat dilihat dari umpan balik atau respon peserta dan panitia yang melaksanakan, PkM GKI Taman Aries panitia termasuk mahasiswa yang membantu pelayanan memberikan umpan balik yaitu :

Kegiatan PkM berjalan lancar, dengan peserta sebanyak 448 orang dan setiap acara sesuai rundown. Dari kegiatan ini terjalin hubungan yang di antara peserta karena dapat berkomunikasi dan tergabung dalam sebuah grup Whatsapp sehingga terbentuk suatu komunitas yang baik, di sini juga para peserta saling membagikan informasi mengenai acara serupa dan mengenai usahanya. Ada beberapa masukkan berupa pengajuan kerjasama dengan pihak GKI Taman Aries ataupun Universitas Pelita Harapan untuk melakukan kegiatan yang sama.

Sedangkan hasil yang diperoleh dari umpan balik atau respon setelah PkM di GKI Kemang Pratama Bekasi: satu adalah topik yang dibawakan penulis (digital marketing/online shop) menurut peserta sangat aplikatif dan lebih bagus karena disertai kasus-kasus terapan. Dua adalah terdapat kendala jaringan dan audio yang perlu dicermati. Tiga adalah slide presentasi ringkas dan mudah diikuti. Empat adalah Presentasi sangat jelas dan membantu. Lima adalah materi dan arahannya jelas, memperkaya wawasan mengenai teknik dan strategi penjualan online.

\section{KESIMPULAN}

Satu adalah Kegiatan PkM tahun 2020 ini berbeda dengan PkM tahun-tahun sebelumnya, perbedaannya terlihat dari beberapa hal seperti terbatasnya pertemuan fisik secara komunal, tidak boleh ada pertemuan lebih dari lima orang (pembatasan jumlah orang berkumpul), peserta PkM bisa dari berbagai tempat atau daerah (bahkan pada PkM di GKI Taman Aries ada yang berasal dari daerah Lampung sampai Papua), acara PkM di GKI Kemang Pratama Bekasi bahkan dibuat live streaming di YouTube. Dua adalah Pembatasan pertemuan secara fisik membuat kegiatan PkM menarik yaitu dapat terbentuknya kegiatan ini tanpa ada pertemuan antara panitia dan penulis sebagai pembicara. Tiga adalah Hasil kegiatan PkM menurut umpan balik dari kedua tempat (GKI Taman Aries dan GKI Kemang Pratama) memperlihatkan bahwa ceramah edukatif mengenai digital marketing atau online shop berjalan baik, lancar dan menambah pengetahuan bagi peserta.

Saran: Kegiatan PkM yang dilakukan secara online perlu kesadaran mengenai kendala yang mungkin terjadi seperti jaringan dan audio dari semua pihak (panitia, pembicara maupun peserta). Selain mengenai jaringan, rekomendasi lain dari penulis adalah sebaiknya kegiatan PkM ini berlanjut dengan melihat perkembangan pengusaha setelah melakukan digital marketing dan dapat mengembangkan pengetahuan lainnya penulis dapat membawakan PkM lanjutan seperti pembelajaran perilaku konsumen atau mempersiapkan kemasan produk maupun pengetahuan lain yang berkaitan dengan bisnis dan pemasaran.

\section{UCAPAN TERIMAKASIH}

Ucapan terimakasih disampaikan kepada: Satu adalah Universitas Pelita Harapan melalui Program Studi Pendidikan Ekonomi yang telah memberikan kesempatan bagi penulis untuk melakukan kegiatan PkM di GKI Taman Aries dan GKI Kemang Pratama Bekasi. Dua adalah LPPM Universitas Pelita Harapan yang telah memberikan kontribusi kepada penulis untuk dapat melaksanakan kedua kegiatan PkM ini dengan No. PM-106-M/FIP/V/2020 dan PM-130$\mathrm{M} / \mathrm{FIP} / \mathrm{VII} / 2020$ 


\section{REFERENSI}

Alma, B. (2005). Manajemen Pemasaran dan Pemasaran Jasa (Edisi Revisi). Cv Alfabeta.

Alma, B. (2009). Kewirausahaan untuk Mahasiswa dan Umum (Revisi). Alfabeta Bandung.

Couter, M., \& Robbins, S. (2009). Manajemen (kedelapan/). PT Index.

Fawaid, Akh. (2017). Pengaruh Digital Marketing System, Terhadap Daya Saing Penjualan Susu Kambing Etawa. Jurnal Ekonomi dan Perbankan Syariah, Vol 4 no. 1: 104-119. P-ISSN: 2354-7057; E-ISSN: 2442-3076.

Hamdan. (2018). Industri 4.0: Pengaruh Revolusi Industri Pada Kewirusahaan Demi Kemandirian Ekonomi. Jurnal Nusantara Aplikasi Manajemen Bisnis, Vol.3 no.2: E-ISSN : 25280929. P-ISSN : 2549 - 5291.

Kasmir. (2017). Kewirausahaan (Ed.Revisi). Rajawali Pers.
Kotler, P., \& Armstrong, G. (2008). Prinsip-Prinsip Pemasaran Jilid 1 (Edisi 12). Penerbit Erlangga.

Kotler, P., Armstrong, G., Ang, S. H., Meng, L. S., Tan, C. T., \& Hon-Ming, O. Y. (2011). Principles of Marketing an Asian Perspective (N. Y. Ling (ed.)). Pearson Education South Asia Pte Ltd.

Santia, T. (2020). Daftar Mal yang Terpaksa Tutup karena Wabah Corona. Liputan6.Com.

Utomo, A. P. (2020). WHO Umumkan Virus Corona sebagai Pandemi Global. KOMPAS.Com. 